\title{
In-hospital mortality risk factors in patients with ascites due to cirrhosis
}

\author{
Miguel Hernan Vicco ${ }^{1 *}$, Luz Rodeles ${ }^{1}$, Franco Ferini ${ }^{1}$, Ana Karina Long ${ }^{1}$, Héctor Mario Musacchio $^{1}$

Study conducted at the Internal Medicine Department, Hospital J. B. Iturraspe, Santa Fe, Argentina

Article received: $4 / 7 / 2014$ Accepted for publication: $6 / 7 / 2014$

*Correspondence: Address: Bv Pellegrini, 3551 Postal Code: 3000 Santa Fe, Argentina mvicco@santafe-conicet.gov.ar

http://dx.doi.org/10.1590/1806-9282.61.01.035 Conflict of interest: none

\section{SUMMARY}

Introduction: ascites is one of the most common complications of cirrhosis associated with a high rate of mortality. Although several scores have been developed in order to assess the prognosis of the disease, they were designed for predicting liver transplantation requirements and mortality in the short term, but not while in hospital. The aim of this study was to weigh risk factors for in-hospital mortality in adult patients with ascites due to alcoholic cirrhosis.

Material and methods: we performed a cross-sectional study in 180 adult patients with diagnosis of cirrhosis with portal hypertension associated with high alcohol intake. The diagnosis of cirrhosis was made by liver echography and portal hypertension was defined by clinical features plus serum-ascites albumin gradient. Sampled individuals were subjected to complete clinical examination. Child Pugh and the MELD scores were applied in all the patients.

Results: nineteen patients died while in-hospital. Mortality was associated with increased levels of serum white blood cell, urea, creatinine, prolonged prothrombin time, aspartate aminotransferase and alanine aminotransferase. We conducted a multiple binary logistic to predict in-hospital mortality which yielded that serum urea, creatinine and prothrombin time made a significant contribution to prediction with an OR $14(95 \%$ CI $12.8-16.7 \mathrm{p}=0.03), 2(95 \%$ CI $0.5-3.47, \mathrm{p}=0.04)$, and $2(95 \%$ CI $1.03-2.31, \mathrm{p}=0.01)$ linearly-related.

Conclusions: our results suggest that acute renal failure and prolonged prothrombin time are predictors of in-hospital mortality in patients with portal hypertension due to alcoholic cirrhosis.

Keywords: ascites, alcoholic, liver cirrhosis, hospital mortality.

\section{INTRODUCTION}

The three most common complications of cirrhosis are ascites, hepatic encephalopathy and variceal hemorrhage. ${ }^{1}$ Ascites usually develops within 10 years during the course of the disease in the $60 \%$ of the patients with compensated cirrhosis, ${ }^{2}$ and it is associated with poor prognosis with a rate of mortality of approximately $40 \%$ after 1 year. ${ }^{3.7}$ The related factors for mortality prediction in patients with ascites include hyponatremia, high serum creatinine and low arterial blood pressure..$^{3-9}$ These patients also have high risk for other complications such as spontaneous bacterial peritonitis (SBP), hyponatremia and hepatorenal syndromes, which increase the risk of fatal outcome. . $^{1,3,7-16}$

Several scores have been developed in order to predict severity of the disease and prognosis in order to consider liver transplantation as a potential treatment option. ${ }^{2}$ These scores are Child Turcotte Pugh and MELD; however, they were designed for predicting liver transplantation requirements and mortality in the short term, but not while in hospital., ${ }^{3,14-21}$ The present study was carried out in order to evaluate risk factors for in-hospital mortality in adult patients with ascites due to alcoholic cirrhosis.

\section{Materials AND METHOdS}

Study population and subject evaluation

We performed a cross sectional study including 180 adult patients with diagnosis of cirrhosis with portal hypertension associated with high alcohol intake. They were all recruited at the Internal Medicine Service of a teaching Hospital in Santa Fe, Argentina, from January of 2008 to 
December of 2010. The diagnosis of cirrhosis was made by liver echography and portal hypertension was defined according to clinical features plus serum-ascites albumin gradient. Sampled individuals were subjected to a complete clinical examination including chest $\mathrm{X}$-ray, and biochemical tests. Exclusion criteria comprised: age $<18$ years, coronary artery disease or history of other cardiac diseases, chronic renal disturbances, immunosuppression or ongoing use of immunosuppressant agents, diabetes, positive serology for viral hepatitis A, B and C, autoimmune hepatitis, hepatorenal syndrome and other systemic complaints. The data recorded included clinical and demographic characteristics of each patient and the variables needed to determine the Child Pugh categories and MELD scores.

The study was approved by the Ethics Review Board of National Coastal University. Informed consent was obtained from all participants. All patients were treated according to local practice and international established guidelines.

\section{Statistical analysis}

Data were analyzed by using MedCalc version 12.2.1. Normal distributions of the continuous variables were tested by Kolmogorov-Smirnov method. The data are expressed as means $\pm \mathrm{SD}$ or median and interquartile range. Chi-square test or Fisher's exact were used for categorical variables, whereas the one-way Anova was used to compare means. A multiple binary logistic regression model was used to assess the impact of variables associated with in-hospital mortality. The Hosmer-Lemeshow test was em- ployed for goodness of fit of the logistic regression model. A p value $<0.05$ was considered significant.

\section{Results}

\section{General population}

We included 180 patients aged $53.6 \pm 10.3$ years (means \pm SD), 140 males and 40 females, with ascites due to portal hypertension. There were no age differences between genders. Nineteen patients died while in hospital. The median time of the admission period of the whole sampled individuals was 41 days. The mean age of the patients who died was $52.8 \pm 11.1$ years (range 43-71). There was no relation between the Child Pugh and MELD scores. In regard to the complications of portal hypertension, 32 individuals presented spontaneous bacterial peritonitis (SBP) and 18 esophageal variceal bleeding. Prolonged prothrombin time was not related with variceal bleeding. The features of the patients stratified by the Child Pugh score are summarized in Table 1.

As shown in Table 1, mortality was not related with age, sex or clinical complications such as SBP or esophageal variceal bleeding. Furthermore, this group presented lower casuistic of spontaneous bacterial peritonitis ( $p<0.0001)$, esophageal variceal bleeding $(0.05)$ and encephalitis ( $\mathrm{p}<0.0001)$. From the whole sampled individuals with SBP, only 17 presented positive ascites cultures to Escherichia coli $(\mathrm{n}=10)$, Klebsiella pneumoniae $(\mathrm{n}=4)$, Streptococcus viridans $(\mathrm{n}=2)$ and Enterococcus faecalis $(\mathrm{n}=1)$. No particular microbe was related to fatal outcome. On the other hand, Child Pugh C group presented higher rate of mortality $(\mathrm{p}=0.04)$.

TABLE 1 Characteristics of the patients. Quantitative variables are expressed as means \pm SD

\begin{tabular}{|c|c|c|c|c|}
\hline & Low risk $(n=41)$ & Intermediate risk $(n=105)$ & High risk $(n=34)$ & $\mathbf{p}$ \\
\hline Age & $43.9 \pm 11.8$ & $51.3 \pm 11.2$ & $67.7 \pm 13.4^{1}$ & $<0.001$ \\
\hline \multicolumn{5}{|l|}{ Gender (n) } \\
\hline Male & 29 & 90 & 21 & NS \\
\hline Female & 12 & 15 & 13 & \\
\hline Systolic blood pressure & $123.8 \pm 15.5 \mathrm{mmHg}$ & $117.2 \pm 16.4 \mathrm{mmHg}$ & $106 \pm 20 \mathrm{mmHg}^{2}$ & 0.001 \\
\hline Diastolic blood pressure & $77.6 \pm 8 \mathrm{mmHg}$ & $70 \pm 10 \mathrm{mmHg}$ & $60 \pm 5 \mathrm{mmHg}^{3}$ & $<0.001$ \\
\hline \multicolumn{5}{|l|}{ Sepsis ( $n)$} \\
\hline Non-septic & 13 & 16 & 6 & $<0.05$ \\
\hline Sepsis & 28 & $76^{4}$ & 23 & \\
\hline Severe sepsis & - & $13^{5}$ & 5 & \\
\hline Admission in the intensive care unit (n) & 6 & $23^{6}$ & 7 & 0.001 \\
\hline Mortality rate $(\mathrm{n})$ & $1^{7}$ & 9 & 13 & 0.001 \\
\hline
\end{tabular}




\section{Prediction of in-hospital mortality}

As mentioned above, SBP was not related to in-hospital mortality. We evaluated if SBP caused by microbes isolated from culture was associated with fatal outcomes, yielding negative results. In relation to biochemical tests, patients who died presented increased levels of serum white blood cell, urea, creatinine, prothrombin time, aspartate aminotransferase and alanine aminotransferase. Also, they had lower ascites albumin concentration and decreased serum-ascites albumin gradient. Then we analyzed the area under the curve (AUC) for each of them, leading to the conclusion that only serum urea, creatinine and prothrombin time had statistically significant AUC of 87\% (95\% CI 81.6 to 91.7, $\mathrm{p}<0.0001), 75 \%$ (95\% CI 68.9 to $81.7, \mathrm{p}=0.0014)$ and $69 \%$ (95\% CI 62.2 to $75.9, \mathrm{p}=0.007$ ), respectively (Figure 1).

Multiple binary logistic regression was conducted to predict in-hospital mortality using the categorical variable Child Pugh, and the continuous variables MELD score, level of serum urea, serum creatinine and prothrombin time. The Wald criterion demonstrated that serum urea, serum creatinine and prothrombin time made a significant contribution to prediction with OR: 14 (95\% CI 12.8 $16.7 \mathrm{p}=0.03), 2$ (95\% CI $0.5-3.47, \mathrm{p}=0.04)$, and 2 (95\% CI $1.03-2.31, \mathrm{p}=0.01)$ linearly-related. The overall model fit Chi-squared was 46.3 ( $p<0.0001)$ with a Hosmer-Leme- show test of $4.54 \mathrm{p}=0.8$, indicating a good logistic regression model fit. The area under the receiver operating characteristic (ROC) curve of the model was 92\% (95\% CI 87.6 - 95.8).

\section{Discussion}

Ascites develops in approximately $60 \%$ of the patients with cirrhosis within 10 years during the course of the disease. Its very presence is an indicator of poor prognosis with a mortality approximately of $40 \%$ after 1 year, and it is suggested that if ascites is diagnosed, liver transplantations should be considered as a treatment option. ${ }^{1,5}$ Furthermore, scores were developed in order to forecast the requirement of liver transplantation or the mortality risk; however, they were designed for short term predictions and not for in-hospital death outcome..$^{2,18-21}$ In our work, we analyzed these variables related to the adverse outcome on admission.

None of the scores were useful to predict in-hospital mortality. Also, despite hyponatremia is described as one of the mortality risk factors, ${ }^{5,15,21}$ it was not related to this outcome in our casuistic. On the other hand, as it was observed previously, ${ }^{5,21-24}$ high serum creatinine presented a significant contribution to prediction. We did not included patients with diagnosis of hepatorenal syndrome, which presents a high mortality rate by itself; however, despite these exclusions, serum creatinine persisted as an

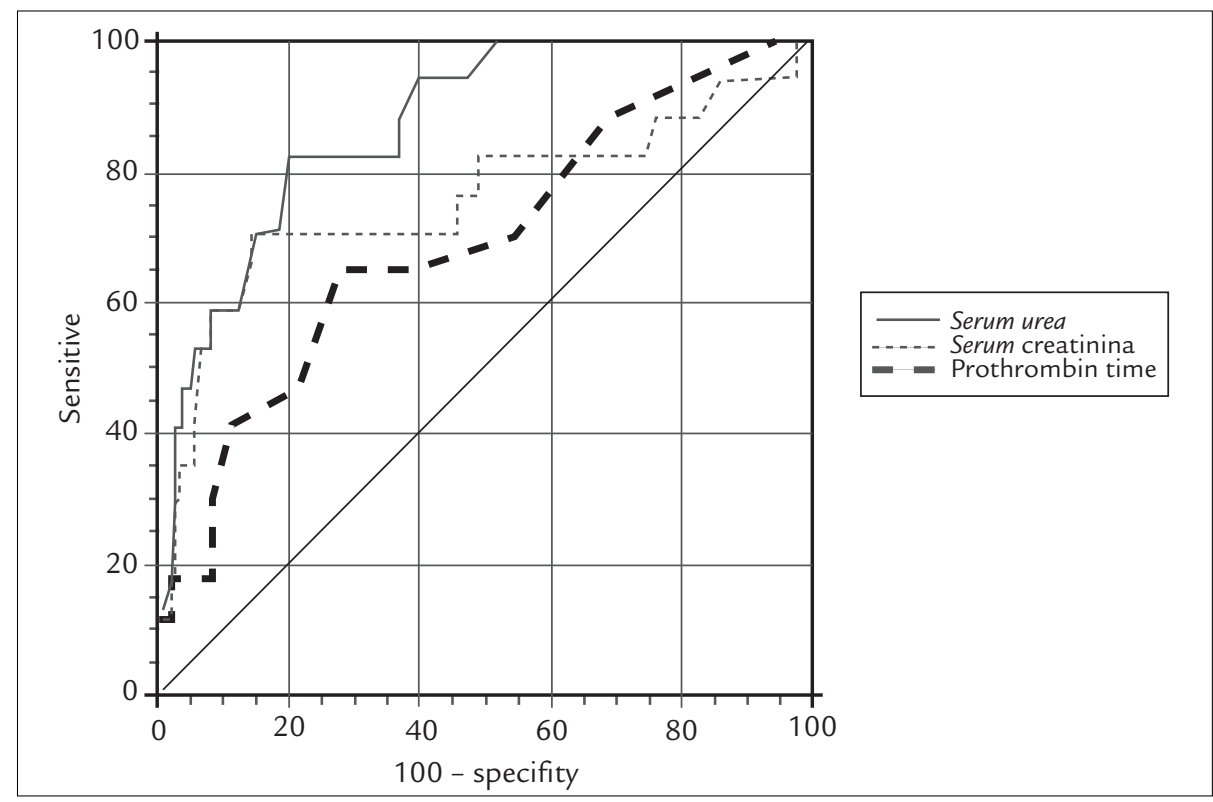

FIGURE 1 Area under the ROC curve for mortality by serum urea, creatinine and prothrombin time.

The associated criterion for serum urea was $0.42 \mathrm{~g} / \mathrm{L}$, with sensitivity of $82.4 \%$ ( $95 \% \mathrm{Cl} 56.6$ to 96.2 ), specificity of $79.9 \%(95 \% \mathrm{Cl} 73$ to 85.6$)$ and positive likelihood ratio of 4 . In the case of serum creatinine criterion value was $1.28 \mathrm{mg} / \mathrm{dL}$ with sensitivity of $70.6 \%(95 \% \mathrm{Cl} 44$ to 89.7$)$, specificity of $86.4 \%(95 \% \mathrm{Cl} 80.3$ to 91.2$)$ and positive likelihood ratio of 5 . Finally for prothrombin time the cut off value was 17 seconds with sensitivity of $64.7 \%(95 \% \mathrm{Cl} 38.3$ to 85.8$)$, specificity of $72.2 \%(95 \% \mathrm{Cl} 64.8$ to 78.8 ) and positive likelihood ratio of 2 . 
indicator of adverse outcome. This variable is used to calculate the MELD score; nevertheless, it has limitations as an estimate of glomerular filtration rate in cirrhosis, so the score possible underestimates the mortality risk in patients with ascites.

Although, similarly to other authors, we observed that serum creatinine is related to mortality, we found two other variables related to the adverse outcome. Prolonged prothrombin time presented a low AUC of $69 \%$ with an odds ratio of 2. This risk factor was not related to esophageal variceal bleeding but it is associated with liver dysfunction, which increases the probability of death in the short term. Last, the other risk factor with a great AUC of $87 \%$ and an odds ratio of 14, was higher level of serum urea. This variable was not described previously as a predictor of mortality in patients with ascites caused by cirrhosis and it is not included in the scores. Despite serum urea level might increase due to hemorrhage, in our casuistry only 18 individuals presented digestive bleeding (esophageal variceal bleeding), most of them in the surviving patient group.

Considering our results, in-hospital mortality was related to acute renal failure with increased levels of serum urea and creatinine and prolonged prothrombin time.

\section{Conclusion}

Our results suggest that acute renal failure and prolonged prothrombin time are predictors of in-hospital mortality in patients with portal hypertension due to alcoholic cirrhosis, despite Child Pugh category or clinical presentation.

\section{LIMITATION OF THE STUDY}

Our study was performed in a single center with a relatively reduced sample size. Also, because it is a cross-sectional study, it is difficult to establish the role of the determined variables as risk factors for in-hospital mortality.

\section{ACKNOWLEDGMENTS}

This work was sponsored by National Coastal University, Argentina. Miguel H. Vicco and Luz Rodeles are researcher fellows of the National Scientific and Technical Research Council.

\section{Resumo}

Fatores de risco de mortalidade intra-hospitalar em pacientes com ascite por cirrose hepática.

Introdução: ascite é uma das complicações mais comuns de cirrose associadas a uma elevada taxa de mortalidade. Embora vários escores tenham sido desenvolvidos a fim de avaliar o prognóstico da doença, eles foram concebidos para prever requisitos de transplante de fígado e mortalidade a curto prazo, mas não durante a internação. $\mathrm{O}$ objetivo deste estudo foi o de pesar fatores de risco para a mortalidade intra-hospitalar em pacientes adultos com ascite decorrente de cirrose alcoólica.

Material e métodos: foi realizado um estudo transversal em 180 pacientes adultos com diagnóstico de cirrose com hipertensão portal, associada à alta ingestão de álcool. O diagnóstico de cirrose foi feita por ecografia hepática e a hipertensão portal foi determinada por características clínicas e pelo gradiente de albumina soro-ascite. Indivíduos avaliados foram submetidos a exame clínico completo. A classificação de Child-Pugh e a escala MELD foram aplicadas em todos os pacientes.

Resultados: dezenove pacientes morreram durante a internação. A mortalidade foi associada ao aumento dos níveis de glóbulos brancos, ureia, creatinina, aspartato aminotransferase, alanina aminotransferase e tempo de protrombina prolongado. Realizamos uma logística binária múltipla para prever a mortalidade intra-hospitalar, que confirmou que ureia, creatinina e tempo de protrombina contribuíram significativamente para a previsão, com uma OR $=14$ (IC 95\% 12,8-16,7 p = 0,03), 2 (IC 95\% $0,5-3,47, \mathrm{p}=0,04)$, e 2 (IC 95\% 1,03-2,31, p = 0,01), relacionada linearmente.

Conclusões: nossos resultados sugerem que a insuficiência renal aguda e de tempo de protrombina prolongado são preditores de mortalidade intra-hospitalar em pacientes com hipertensão portal decorrente de cirrose alcoólica.

Palavras-chave: ascite, alcoólico, cirrose hepática, mortalidade hospitalar.

\section{REFEREnCES}

1. Ginés P, Quintero E, Arroyo V, Terés J, Bruguera M, Rimola A, et al. Compensated cirrhosis: natural history and prognostic factors. Hepatology 1987;7:122-28.

2. Runyon BA. Management of adult patients with ascites due to cirrhosis: update 2012. Hepatology. 2009; 49(6):2087-107.

3. Planas R, Montoliu S, Balleste B, Rivera M, Miguel M, Masnou H, et al. Natural history of patients hospitalized for management of cirrhotic ascites. Clin Gastroenterol Hepatol 2006;4:1385-394.

4. Lucena MI, Andrade RJ, Tognoni G, Hidalgo R, de la Cuesta FS, Fraile JM, et al. Multicenter hospital study on prescribing patterns for prophylaxis and treatment of complications of cirrhosis. Eur J Clin Pharmacol 2002;58:435-40.

5. Marchesini G, Bianchi G, Amodio P, Salerno F, Merli M, Panella C, et al. Factors associated with poor health-related quality of life of patients with cirrhosis. Gastroenterology 2001;120:170-178.

6. Moller $\mathrm{S}$, Henriksen JH. The systemic circulation in cirrhosis. In: Ginès $\mathrm{P}$, Arroyo V, Rodés J, Schrier RW, editors. Ascites and renal dysfunction in liver disease. Malden: Blackwell; 2005. p. 139-55.

7. Guevara M, Cárdenas A, Uriz J, Ginès P. Prognosis in patients with cirrosis and ascites. In: Ginès P, Arroyo V, Rodés J, Schrier RW, editors. Ascites and 
renal dysfunction in liver disease: pathogenesis, diagnosis and treatment. Malden: Blackwell; 2005. p. 260-70.

8. Ginès P, Schrier RW. Renal failure in cirrhosis. N Engl J Med 2009;361:1279-90.

9. Llach J, Ginès P, Arroyo V, Rimola A, Titó L, Badalamenti S, et al. Prognostic value of arterial pressure, endogenous vasoactive systems and renal function in cirrhotic patients admitted to the hospital for the treatment of ascites. Gastroenterology 1988;94:482-87

10. Moore KP, Wong F, Gines P, Bernardi M, Ochs A, Salerno F, et al. The management of ascites in cirrhosis: report on the consensus conference of the International Ascites Club. Hepatology 2003; 38(1):258-66.

11. Arroyo V, Ginès P, Gerbes AL, Dudley FJ, Gentilini P, Laffi G, et al. Definition and diagnostic criteria of refractory ascites and hepatorenal syndrome in cirrhosis. Hepatology 1996; 23:164-76.

12. Salerno F, Gerbes A, Ginès P, Wong F, Arroyo V. Diagnosis, prevention and treatment of hepatorenal syndrome in cirrhosis. Postgrad Med J. 2008; 84(998):662-70

13. Myers RP, Quan H, Hubbard JN, Shaheen AA, Kaplan GG. Predicting inhospital mortality in patients with cirrhosis: results differ across risk adjustment methods. Hepatology 2009; 49(2):568-77.

14. Lippi G, Danese E, Cervellin G, Montagnana M. Laboratory diagnostics of spontaneous bacterial peritonitis. Clin Chim Acta 2014; 430C:164-70.

15. Kim WR, Biggins SW, Kremers WK, Wiesner RH, Kamath PS, Benson JT, et al. Hyponatremia and mortality among patients on the liver transplant waiting list. N Engl J Med 2008; 359:1018-26.

16. Chaulk J, Carbonneau M, Qamar H, Keough A, Chang HJ, Ma M, et al. Thirdgeneration cephalosporin-resistant spontaneous bacterial peritonitis: A single-centre experience and summary of existing studies. Can J Gastroenterol Hepatol 2014; 28(2):83-8.
17. European Association for the Study of the Liver. EASL clinical practice guidelines on the management of ascites, spontaneous bacterial peritonitis, and hepatorenal syndrome in cirrhosis. J Hepatol 2010; 53(3):397-417.

18. Rahimi-Dehkordi N, Nourijelyani K, Nasiri-Tousi M, Ghodssi-Ghassemabadi R, Azmoudeh-Ardalan F, Nedjat S. Model for End stage Liver Disease (MELD) and Child-Turcotte-Pugh (CTP) scores: Ability to predict mortality and removal from liver transplantation waiting list due to poor medical conditions. Arch Iran Med. 2014; 17(2):118-21.

19. Guardiola J, Baliellas C, Xiol X, Fernandez EG, Ginès P, Ventura P, et al. External validation of a prognostic model for predicting survival of cirrhotic patients with refractory ascites. Am J Gastroenterol 2002; 97:2374-2378.

20. Kamath PS, Wiesner RH, Malinchoc M, Kremers W, Therneau TM, Kosberg $\mathrm{CL}$, et al. A model to predict survival in patients with end-stage liver disease. Hepatology 2001; 33:464-70.

21. Durand F, Valla D. Assessment of prognosis in cirrhosis. Semin Liver Dis $2008 ; 28: 110-22$.

22. Rimola A, Gracia-Tsao G, Navasa M, et al. Diagnosis, treatment and prophylaxis of spontaneous bacterial peritonitis: a consensus document. International Ascites Club. J Hepatol 2000; 32:142-53.

23. Caregaro L, Menon F, Angeli P, et al. Limitations of serum creatinine level and creatinine clearance as filtration markers in cirrhosis. Arch Intern Med 1994; 154:201-5

24. Terg R, Gadano A, Cartier M, Casciato P, Lucero R, Muñoz A, et al. Serum creatinine and bilirubin predict renal failure and mortality in patients with spontaneous bacterial peritonitis: a retrospective study. Liver Int 2009; 29:415-19 